\title{
Novel photochemical reactions of carbocyclic diazodiketones without elimination of nitrogen - a suitable way to $\mathrm{N}$-hydrazonation of $\mathrm{C}-\mathrm{H}$-bonds
}

\author{
Liudmila L. Rodina ${ }^{1}$, Xenia V. Azarova ${ }^{1}$, Jury J. Medvedev ${ }^{1}$, Dmitrij V. Semenok ${ }^{2}$ \\ and Valerij A. Nikolaev*1
}

\section{Full Research Paper}

\section{Address:}

${ }^{1}$ Department of Organic Chemistry, St-Petersburg State University, 26 University pr., 198504, Saint-Petersburg, Russia and ${ }^{2}$ Skolkovo Institute of Science and Technology, 143026, Moscow, Skolkovo Innovation Center, 3 Nobel st., Russia

Email:

Valerij A. Nikolaev* - valerij.nikolaev@gmail.com

${ }^{*}$ Corresponding author

Keywords:

$\mathrm{C}-\mathrm{H}$ insertion; diazo compounds; excited state; photochemistry; Wolff rearrangement

\author{
Beilstein J. Org. Chem. 2018, 14, 2250-2258. \\ doi:10.3762/bjoc. 14.200 \\ Received: 24 April 2018 \\ Accepted: 09 August 2018 \\ Published: 28 August 2018 \\ Associate Editor: J. A. Murphy \\ (C) 2018 Rodina et al.; licensee Beilstein-Institut. \\ License and terms: see end of document.
}

\begin{abstract}
The sensitized photoexcitation of 2-diazocyclopentane-1,3-diones in the presence of THF leads to the insertion of the terminal $\mathrm{N}$-atom of the diazo group into the $\alpha-\mathrm{C}-\mathrm{H}$ bond of THF, producing the associated $N$-alkylhydrazones in yields of up to $63-71 \%$. Further irradiation of hydrazones derived from furan-fused tricyclic diazocyclopentanediones culminates in the cycloelimination of furans to yield 2- $\mathrm{N}$-(alkyl)hydrazone of cyclopentene-1,2,3-trione. By contrast, the direct photolysis of carbocyclic diazodiketones gives only Wolff rearrangement products with up to $90-97 \%$ yield.
\end{abstract}

\section{Introduction}

Photochemical reactions of diazocarbonyl compounds are wellknown transformations in the synthesis of the diversified acyclic, carbo- and heterocyclic structures [1-5]. A direct irradiation of diazo compounds by UV light usually gives rise to nitrogen elimination and generation of carbenes [6-10] or ketenes [11-18] and their ensuing transformations. On the other hand, photochemical reactions of diazocarbonyl compounds without elimination of dinitrogen are essentially limited to their isomerization into $\alpha$-ketodiazirines [19-26] which is usually ob- served upon irradiation of diazo compounds with longer wavelength UV light.

Recently a new light-induced reaction of diazo compounds with retention of the diazo group nitrogen atoms in the structure of the reaction products was discovered by our group. The sensitized photoexcitation of heterocyclic diazoketones - diazotetrahydrofuranones resulted in the formation of $N$-alkyl-substituted hydrazones and other nitrogen-containing compounds [27- 
30]. This photochemical process is assumed to proceed through the triplet excited states of diazoketones via 'insertion' of the terminal nitrogen atom of the diazo group into the $\mathrm{C}-\mathrm{H}$ bond of the organic substrates $[27,30]$.

Hence it was principally demonstrated that by carefully varying the irradiation conditions one can direct the photochemical reaction of diazo compounds at the alternative way, which provides the retention of 'dinitrogen' in the structure of molecule formed. It is reasonable that a question arises on the scope and limitations of this new light-induced reaction of diazo compounds.

The main objective of our current research was to elucidate the possibility of using carbocyclic diazodiketones in this photochemical process. For this purpose, diazocyclopentanediones 1a-g were tested in the study including unsubstituted diazocyclopentanedione 1a, tricyclic diazodiketones $\mathbf{1 b}-\mathbf{e}$ with $\mathrm{CH}_{2}-$ and O-bridges in their structure, diazoindandione 1f, diazocyclopentenedione $\mathbf{1 g}$, and as a $\mathrm{C}-\mathrm{H}$ donor tetrahydrofuran was employed in the study (Figure 1).

To determine the most efficient conditions for this reaction with diazodiketones $\mathbf{1}$, three sensitizers, acetophenone, benzophenone, and Michler's ketone, with different levels of triplet state energy were tested. Furthermore, to clearly demonstrate the difference of light-induced reactions of diazo compounds 1 in the triplet and singlet excited states, the direct photolysis of diazodiketones 1a-c without sensitizers was also examined.

\section{Results and Discussion}

The starting diazocyclopentanediones (DDK, 1a-f) were synthesized from the corresponding 1,3-dicarbonyl compounds [31-33] employing a diazotransfer reaction [34-39]. Diazocyclopentenedione $1 \mathrm{~g}$ was prepared by thermal cycloelimination from diazodiketones 1d,e [38,39]. The structures of diazodiketones 1a-g were established using a standard set of spectroscopic methods $\left({ }^{1} \mathrm{H}\right.$ and ${ }^{13} \mathrm{C}$ NMR, IR and UV; for details, see Sup- porting Information File 1, Table S1) and in the case of the tricyclic diazodiketone 1c the structure was also confirmed by means of X-ray analysis (Supporting Information File 1, Figure $\mathrm{S} 1)$. As it is evident from these data, the tricyclic diazodiketones $\mathbf{1 b}-\mathbf{e}$ all have endo-configuration of the molecular structure.

Analysis of the UV spectra of diazodiketones 1 shows that they have four absorption bands: two intense ones at 216-222 and 248-250 nm, and two bands with very week intensities at $311-316 \mathrm{~nm}(215<\varepsilon<290)$ and $363-367 \mathrm{~nm}(30<\varepsilon<49)$ (see Supporting Information File 1, Table S1). By analogy with the literature data [40], the absorption bands in the short wavelength region $(216-250 \mathrm{~nm})$ are attributed to $\pi-\pi^{*}$ electronic transitions, whereas the long wavelength bands are most likely caused by $n-\pi *$ transitions. Based on the position of the long wavelength bands $(363-367 \mathrm{~nm})$ the energy of the singlet excited state ${ }^{1} \mathrm{~S}_{1}$ of diazodiketones $\mathbf{1}$ can be estimated at about $78-79 \mathrm{kcal} / \mathrm{mol}[41]$.

The characteristics of the absorption bands of the sensitizers used in this study (acetophenone, benzophenone and Michler's ketone) demonstrate that they show appropriate absorption of the actinic light at the irradiation conditions of diazodiketones $\mathbf{1}$ (Supporting Information File 1, Table S2).

The sensitized photoreactions of diazodiketones $\mathbf{1 a}-\mathbf{g}$ were carried out in THF solutions with added sensitizers (Table 1). In the case of diazodiketone 1a the only isolated product was hydrazone 2 a with $33-49 \%$ yields (Table 1, entries 1-3). Increasing the amount of sensitizer (up to 10:1) enhanced the yield of hydrazone $2 \mathrm{a}$ by $1 / 2$ while reducing the irradiation time by $50 \%$ (Table 1, entries 1 and 3 ).

The irradiation of tricyclic diazodiketone $\mathbf{1 b}$ in the presence of 1 equiv of benzophenone in THF solution led to the formation of hydrazone $\mathbf{2 b}$ in a yield of $32 \%$ (Table 1, entry 4 ), whose<smiles>N=C1CCC(=O)C1=O</smiles>

1a<smiles>N=C1C(=O)C2C3C=CC(C3)C2C1=O</smiles>

$1 \mathrm{~b}$<smiles>N=C1C(=O)C2C3CCC(C3)C2C1=O</smiles>

1c<smiles>N=C1C(=O)C2C3C=CC(O3)C2C1=O</smiles>

1d<smiles>CC12C=CC(O1)C1C(=O)C(=N)C(=O)C12</smiles>

$1 e$<smiles>N=c1c(=O)c2ccccc2c1=O</smiles>

$1 f$<smiles>N=c1c(=O)ccc1=O</smiles>

$1 \mathrm{~g}$

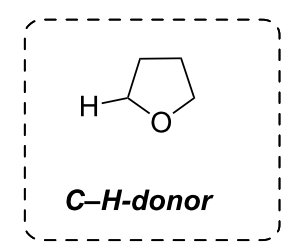

Figure 1: The structures of carbocyclic diazodiketones $1 \mathrm{a}-\mathrm{g}$ and $\mathrm{C}-\mathrm{H}$-donating tetrahydrofuran used in the project. 
Table 1: Sensitized light-induced reactions of diazodiketones $1 \mathrm{a}-\mathrm{f}^{\mathrm{a}}$

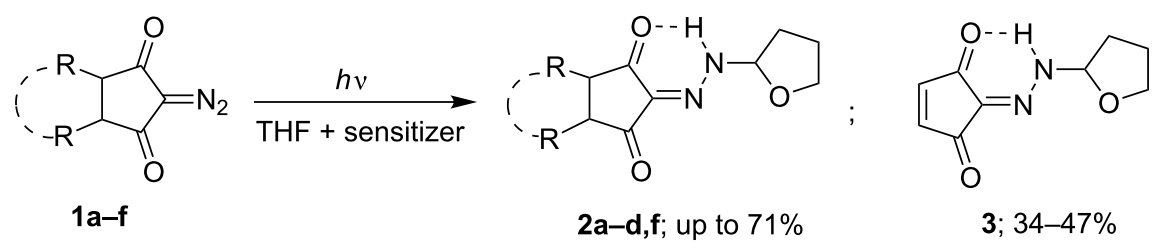

\begin{tabular}{|c|c|c|c|c|c|}
\hline Entry & $\mathrm{DDK}^{\mathrm{b}}$ & Sensitizer & Ratio sensitizer/DDK & Time, $\mathrm{h}$ & Yields of $\mathbf{2 a - d , f}$ and $\mathbf{3}$ [\%] \\
\hline 1 & & & $2: 1$ & 1.5 & $2 a ; 33$ \\
\hline 2 & $1 a$ & $\mathrm{Ph}_{2} \mathrm{CO}$ & $4: 1$ & 0.75 & $2 a ; 42$ \\
\hline 3 & & & $10: 1$ & 0.75 & $2 a ; 49$ \\
\hline 4 & & $\mathrm{Ph}_{2} \mathrm{CO}$ & $1: 1$ & 1.3 & $2 b ; 32$ \\
\hline $5^{c}$ & & $\mathrm{Ph}_{2} \mathrm{CO}$ & $1: 1$ & 6.5 & $2 b ; 34$ \\
\hline 6 & $1 b$ & $\mathrm{Ph}_{2} \mathrm{CO}$ & $4: 1$ & 2 & $2 b ; 52$ \\
\hline 7 & & $\mathrm{Ph}_{2} \mathrm{CO}$ & $10: 1$ & 1.5 & $2 b ; 71$ \\
\hline 8 & & $\mathrm{MePhCO}$ & $4: 1$ & 1.5 & $2 \mathbf{b} ; 40$ \\
\hline 9 & & $\mathrm{MK}^{\mathrm{d}}$ & $2: 1$ & 3.5 & n.d. ${ }^{e}$ \\
\hline 10 & 1c & $\mathrm{Ph}_{2} \mathrm{CO}$ & $10: 1$ & 0.8 & 2c; 63 \\
\hline 11 & 1d & $\mathrm{Ph}_{2} \mathrm{CO}$ & $4: 1$ & 0.5 & $2 \mathrm{~d} ; 35+3 ; 47$ (total yield $82 \%$ ) \\
\hline 12 & $1 e$ & $\mathrm{Ph}_{2} \mathrm{CO}$ & $4: 1$ & 1.0 & $3 ; 34$ \\
\hline 13 & $1 f$ & $\mathrm{Ph}_{2} \mathrm{CO}$ & $4: 1$ & 0.8 & 2f; 52 \\
\hline
\end{tabular}

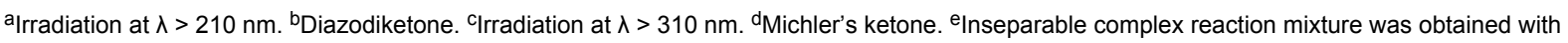
Michler's ketone.

structure was unambiguously established by X-ray analysis (Figure 2).

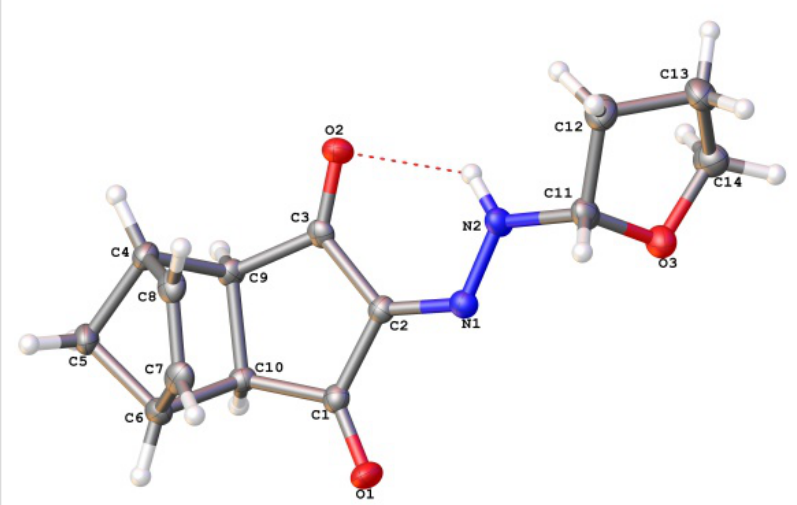

Figure 2: Molecular structure of hydrazone $\mathbf{2} \mathbf{b}$ as determined by $\mathbf{X}$-ray analysis data (Olex2 plot with $50 \%$ probability level of ellipsoids).

To increase the yields of hydrazones $\mathbf{2}$, an effort was undertaken to optimize the photochemical reaction conditions by varying the wavelength of irradiation, sensitizer, as well as the ratio of sensitizer/diazodiketone $\mathbf{1 b}$ (Table 1, entries 4-9).
As can be seen from the data in Table 1 the most effective sensitizer for the light-induced reaction studied in the series of acetophenone, benzophenone, and Michler's ketone was found to be benzophenone. The application of acetophenone reduced the yield of hydrazone $\mathbf{2 b}$ by about $1 / 4$ as compared to benzophenone (from 52 to $40 \%$; Table 1, entries 6 and 8). With Michler's ketone, a complex product mixture was obtained, from which it was impossible to isolate pure compounds.

When varying the ratio of sensitizer/diazodiketone $\mathbf{1 b}$, the best result was obtained with a 10 -fold excess of benzophenone (Table 1, entry 7; 71\% yield). Application of a 4 -fold excess of this sensitizer diminished the yield of hydrazone $\mathbf{2 b}$ to $52 \%$ (Table 1, entry 6$)$. In going from short wavelength $(\lambda>210 \mathrm{~nm})$ to longer wavelength $(\lambda>310 \mathrm{~nm})$ irradiation, the yield of hydrazone $\mathbf{2 b}$ remained practically unchanged, however the reaction time considerably increased from 1.3 to $6.5 \mathrm{~h}$; Table 1 , entries 4 and 5).

The reactions of tricyclic diazodiketone 1c and diazoindandione $\mathbf{1 f}$ in the presence of benzophenone as sensitizer proceeded in a similar way to diazo compound $\mathbf{1 b}$ under the 
optimal conditions affording hydrazones $\mathbf{2 c , f}$ in yields of 63 and $52 \%$, respectively (Table 1 , entries 10 and 13 ).

An unexpected side reaction was observed during irradiation of furan-fused tricyclic diazodiketones $\mathbf{1 d , e}$ (Scheme 1). In the case of diazodiketone 1d, hydrazone 3 (47\%) was isolated from reaction mixture in addition to the expected hydrazone $\mathbf{2 d}$ (35\%; total yield $82 \%$, Table 1, entry 11 ), whereas the same reaction with diazodiketone $1 \mathrm{e}$ afforded hydrazone $\mathbf{3}$ exclusively (Table 1 , entry 12).

Additional experiments showed that hydrazone 3 was not formed on sensitized photoexcitation of diazocyclopentenedione $\mathbf{1 g}$ in the presence of the $\mathrm{C}-\mathrm{H}$-donor THF (Scheme 1). Thus one can conclude that product $\mathbf{3}$ is generated by a light-induced cycloelimination of furan from the initially generated tricyclic hydrazones $\mathbf{2 d , e . ~}$

Hence it was established that the sensitized photoexcitation of diazodiketones 1a-d,f in THF solution proceeds through the insertion of the terminal $\mathrm{N}$-atom of the diazo group in the $\alpha-\mathrm{C}-\mathrm{H}-$ bond of THF with the formation of the appropriate hydrazones $\mathbf{2 a - d , f}$ and the most effective sensitizer for this reaction was found to be benzophenone.

The direct photolysis of diazodiketones 1a-c was carried out by UV light $(\lambda>210 \mathrm{~nm})$ in THF solution containing a small amount of $\mathrm{H}_{2} \mathrm{O}$ or $\mathrm{MeOH}$ to trap the proposed intermediate $\alpha$-oxoketene. These light-induced processes with diazodiketones 1 a-c resulted in formation of 2-oxocyclobutanecarboxylic acid 4a or methyl esters $\mathbf{5 a}-\mathbf{c}$ in high isolated yields of up to $90 \%$ (Table 2). At the same time no insertion products of the possible intermediate dioxocarbenes into $\mathrm{O}-\mathrm{H}$-bonds of the nucleophilic reagents $\left(\mathrm{H}_{2} \mathrm{O}, \mathrm{MeOH}\right)$ or $\mathrm{C}-\mathrm{H}$-bonds at $\mathrm{C}^{5}$ or $\mathrm{C}^{6}$ atoms in 1 [26,42-45] were detected in the reaction mixtures. Thus, it was experimentally shown that the direct photolysis of diazodiketones 1a-c employing UV light with $\lambda>210 \mathrm{~nm}$ produces only Wolff rearrangement products in high yields.

The structure of 2-oxocyclobutanecarboxylic acid $\mathbf{4 a}$ and the methyl esters $\mathbf{5 a}-\mathbf{c}$ was established by spectroscopic data $\left({ }^{1} \mathrm{H},{ }^{13} \mathrm{C} \mathrm{NMR}\right.$, and HRMS), and in case of $\mathbf{4 a}$ and $\mathbf{5 a}$, also confirmed by comparison with the known literature data [46-48].
$1 d, e$

$$
\underset{\mathrm{THF}}{\stackrel{h v ; \mathrm{Ph}_{2} \mathrm{CO}}{\longrightarrow}}
$$<smiles>[R]C12C=CC(O1)C1C(=O)C(=NNC3CCCO3)C(=O)C12</smiles>

2d,e<smiles>[R]c1ccc(C)o1</smiles>

$\mathrm{R}=\mathrm{H}, \mathrm{Me}$<smiles>O=c1ccc(=O)c1=NNC1CCCO1</smiles>

3

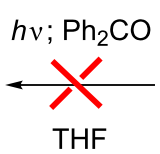

THF<smiles>N=c1c(=O)ccc1=O</smiles>

$1 \mathrm{~g}$

Scheme 1: Photochemical cycloelimination of furans from hydrazones $\mathbf{2 d , e . ~}$

Table 2: Direct photolysis of diazodiketones 1a-c by UV light with $\lambda>210 \mathrm{~nm}$.<smiles>[R]C1C(=O)C(=NC#N)C(=O)C1[R]([H])[H]</smiles>

$1 a-c$<smiles>NC(=O)C1C(=O)C2CCPC21</smiles>

4a; $90 \%(\mathrm{Nu}=\mathrm{OH})$ 5a-c; $79-86 \%(\mathrm{Nu}=\mathrm{OMe})$

\section{$4 a, 5 a$ $\mathrm{H}_{2} \mathrm{O}\left(\mathrm{SiO}_{2}\right)$}<smiles>[R]C(CC([N+])=O)C([R])C(=O)O</smiles>

$\mathrm{R}=\mathrm{H}$ up to $100 \%$

\begin{tabular}{|c|c|c|c|c|}
\hline Entry & DDK 1a-c & Solvent/NuH (ratio) & Time, $\min$ & Yields of $4,5[\%]^{a}$ \\
\hline 1 & $1 a$ & $\mathrm{THF} / \mathrm{H}_{2} \mathrm{O}(45: 1)$ & 50 & $\mathbf{4 a} ; 90$ \\
\hline 2 & $1 a$ & THF/MeOH $(20: 1)$ & 55 & $\mathbf{5 a} ; 86$ \\
\hline 3 & $1 b$ & THF/MeOH (200:1) & 55 & 5b; $79(97)$ \\
\hline 4 & $1 c$ & THF/MeOH (50:1) & 45 & $5 c ; 82$ \\
\hline
\end{tabular}

aYield determined by ${ }^{1} \mathrm{H}$ NMR spectroscopy is given in parenthesis. 
It was found that 2-oxocyclobutanecarboxylic acid $\mathbf{4 a}$ and ester 5a were easily hydrolyzed in the presence of $\mathrm{H}_{2} \mathrm{O}$ or during chromatography on silica gel to produce glutaric acid and the corresponding methyl ester (Table 2). By contrast, esters $\mathbf{5 b}, \mathbf{c}$ proved to be much more stable to hydrolysis on $\mathrm{SiO}_{2}$ and in the presence of nucleophilic reagents. For example, when heating in boiling $\mathrm{MeOH}$ for $2 \mathrm{~h}$ no hydrolysis of ketoester $\mathbf{5 c}$ occurs according to ${ }^{1} \mathrm{H}$ NMR spectra.

The assumed ways for light-induced reactions of diazodiketones 1 can be represented as follows. The direct irradiation $(\lambda>210 \mathrm{~nm})$ of diazodiketones 1 gives rise to accumulation of one of their upper singlet excited states ${ }^{1}(\mathbf{1}) *[13,15,18,20,49$ 51] which turn into usual Wolff rearrangement products, i.e., highly reactive oxoketenes 6 (Scheme 2 , reaction I). The intermediate ketenes 6 react with $\mathrm{H}_{2} \mathrm{O}$ or $\mathrm{MeOH}$ present in the reaction mixture to give 2-oxocarboxylic acid $4 \mathbf{a}$ or esters $\mathbf{5 a}-\mathbf{c}$.

On the other hand, the sensitized photoexcitation of diazodiketones 1 gives rise to generation of triplet excited states of diazo compounds ${ }^{3}(\mathbf{1})_{1}$ which interact with the H-donor (tetrahydrofuran) producing $\mathrm{N}$-alkyl-substituted hydrazones 2 (Scheme 2, reaction II). Based on the comparison study of the sensitizers' efficiency in this reaction (Table 2) one can conclude [41,52], that the energy of the triplet excited states ${ }^{3} \mathrm{~T}_{1}$ of diazodiketones 1 are about $68 \mathrm{kcal} / \mathrm{mol}$. This provides a possible explanation why the use of Michler's ketone was found to be ineffective as a photosensitizer in the process. The energy of the triplet excited state ${ }^{3} \mathrm{~T}_{1}$ of this sensitizer $(64 \mathrm{kcal} / \mathrm{mol})$ is somewhat lower than the corresponding energy of the diazodiketones 1 making it inadequate to initiate the $\mathrm{C}-\mathrm{H}$ insertion reaction. On the other hand, the triplet excited state energy of benzophenone $(69 \mathrm{kcal} / \mathrm{mol})$ renders it a suitable sensitizer for this reaction.

In the case of tricyclic diazodiketones $\mathbf{1 d , f}$ (with annulated furan and 2-methylfuran-motifs in their structures), a tandem photochemical process of $\mathrm{C}-\mathrm{H}$-insertion followed by cycloelimination of furan from the initially generated hydrazones $\mathbf{2 d , f}$ apparently occurs, giving rise to the formation of hydrazone 3 as the final reaction product (Scheme 1).

On direct irradiation of tricyclic diazodiketones 1 possessing endo-configuration (Figure 2), one would expect in addition to the Wolff rearrangement also the occurrence of an intramolecular cyclopropanation (with $\mathbf{1 b}, \mathbf{d}, \mathbf{e}$ ) [53-55] or an insertion of the assumed intermediate dioxocarbenes in $\mathrm{C}-\mathrm{H}$-bonds at $\mathrm{C}^{5}$ or $\mathrm{C}^{6}$-atoms (with 1c) [26,42-45]. However, the performed experiments did not confirm the formation of corresponding reaction products in the photochemical reactions studied. This can be considered as an argument in favor of the concerted Wolff rearrangement [11-18] in the case of these diazodiketones.

\section{Conclusion}

The sensitized photoexcitation of carbocyclic diazodiketones proceeds without elimination of dinitrogen. Instead, the reaction leads to the insertion of the terminal $\mathrm{N}$-atom of the diazo group into the $\mathrm{C}-\mathrm{H}$ bond of THF giving rise to the appropriate $\mathrm{N}$-alkyl-substituted hydrazones in yields of up to $63-71 \%$. The most powerful sensitizer for this light-induced process in the series of acetophenone, benzophenone and Michler's ketone was found to be benzophenone. Hence, the diazodicarbonyl compounds can be successfully used for a photochemical $\mathrm{N}$-functionalization of $\mathrm{C}-\mathrm{H}$-bonds of organic compounds. In contrast to this, the direct photolysis of carbocyclic diazoketones produces exclusively Wolff rearrangement products in yields of $90-97 \%$.

\section{Experimental General methods}

All reactions were carried out under argon atmosphere in solvents that were purified and dried before use by common methods. Monitoring of the reaction course was accomplished by thin layer chromatography (TLC) on silica gel SIL G/UV254

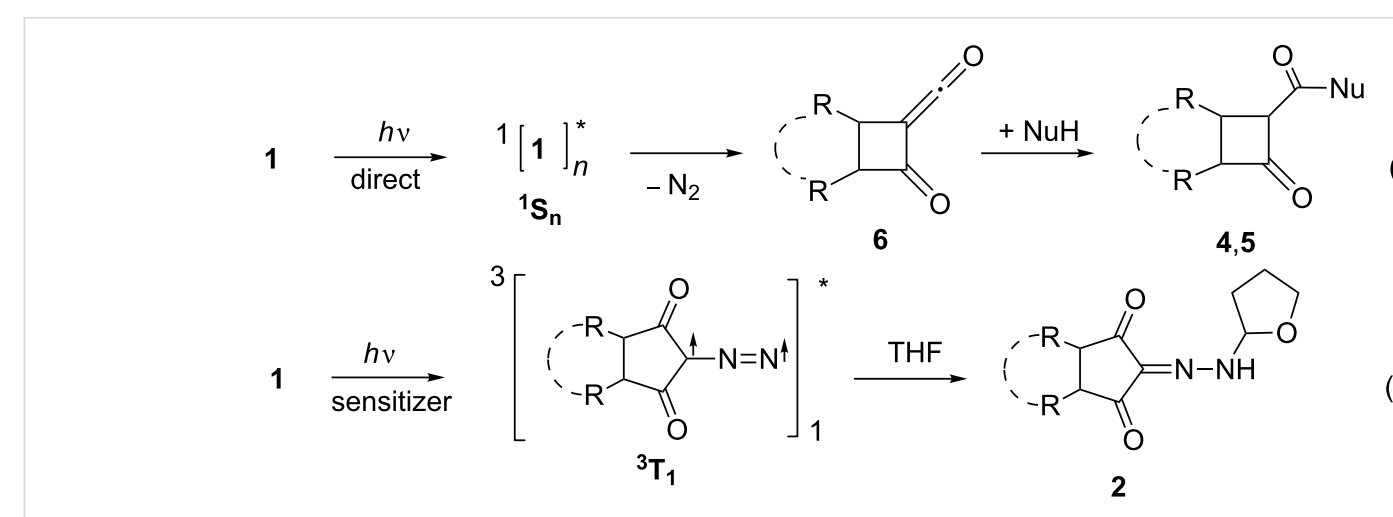


plates (Marcherey, Nagel \& Co.). Chromatography was performed using Merck silica gel 60, 230-400 mesh. ${ }^{1} \mathrm{H}$ and ${ }^{13} \mathrm{C}$ NMR spectra were recorded using a Bruker-400 Avance NMR spectrometer. All HRMS spectra were recorded on a «MaXis» (Bruker Daltonik GmbH), the HPLC system (UHPLC) with the combined high-resolution quadrupole-timeof-flight mass spectrometer with electrospray ionization (ESIQTOF). Chemical shifts are reported in ppm, and coupling constants are given in hertz $(\mathrm{Hz})$. All signals in NMR spectra were normalized relative to signals of $\mathrm{CHCl}_{3}(\delta=7.26 \mathrm{ppm}$ in $\left.{ }^{1} \mathrm{H} \mathrm{NMR}\right)$ and $\mathrm{CDCl}_{3}\left(\delta=77.0\right.$ in ${ }^{13} \mathrm{C}$ NMR spectra $)$.

For single crystal X-ray diffraction experiments of 1c (CCDC 1584937) and 2b (CCDC 1584938) an Agilent Technologies «Xcalibur» diffractometer with monochromated MoK $\alpha$ radiation was used. All samples were measured at $100 \mathrm{~K}$. The unit cell parameters were refined by least square techniques in CrysAlisPro (Agilent Technologies, 2012) program complex. Empirical absorption correction was applied using spherical harmonics, implemented in SCALE3 ABSPACK scaling algorithm. The structures were solved by the Superflip [56-58] and ShelXS [59] structure solution programs using Charge Flipping and Direct Methods, respectively, then refined by means of the ShelXL [60] program, incorporated in the Olex2 program package [61].

\section{Sensitized reactions of diazodiketones $\mathbf{1 a - g}$}

General procedure. The solution of diazodiketone $\mathbf{1 a - g}$ ( 1 equiv) and benzophenone (up to 10 equiv) in THF $(10-30 \mathrm{ml})$ was irradiated in a quartz reactor $(\lambda>210 \mathrm{~nm})$ under an argon atmosphere for up to $6.5 \mathrm{~h}$ (control of the reacted diazodiketone 1 by TLC). Thereupon the reaction mixture was dried over magnesium sulfate, the solvent completely distilled off in vacuum and the residue separated by column chromatography $\left(\mathrm{SiO}_{2}\right.$, eluent: petroleum ether $\rightarrow$ petroleum ether/acetone 8:1) to give the hydrazones $\mathbf{2}$ and $\mathbf{3}$.

\section{A. Sensitized photoexcitation of 2-diazocyclopentane-1,3- dione (1a). The reaction was performed according to the general procedure with $496 \mathrm{mg}$ ( $4 \mathrm{mmol}, 1$ equiv) of diazodike- tone 1a and $2.912 \mathrm{~g} \mathrm{(16} \mathrm{mmol,} 4$ equiv) of benzophenone in $30 \mathrm{ml}$ of THF with an irradiation time of $45 \mathrm{~min}$. After the workup procedure hydrazone $\mathbf{2 a}$ and unreacted diazoketone 1a were isolated.}

2-(2-(Tetrahydrofuran-2-yl)hydrazono)cyclopentane-1,3dione (2a). Yield $168 \mathrm{mg}$ (42\%, calculated on the reacted diazodiketone 1a), bright-yellow oil; ${ }^{1} \mathrm{H}$ NMR $(400 \mathrm{MHz}$, $\left.\mathrm{CDCl}_{3}, \delta\right) 12.93(\mathrm{~s}, 1 \mathrm{H}), 5.61-5.53(\mathrm{~m}, 1 \mathrm{H}), 4.08-3.99(\mathrm{~m}, 1 \mathrm{H})$, $3.95-3.88(\mathrm{~m}, 1 \mathrm{H}), 2.69-2.60(\mathrm{~m}, 4 \mathrm{H}), 2.33-2.19(\mathrm{~m}, 2 \mathrm{H})$, 2.08-1.96 (m, 2H) ppm; $\left.{ }^{13} \mathrm{C} \mathrm{NMR} \mathrm{(101} \mathrm{MHz,} \mathrm{CDCl}_{3}, \delta\right) 200.3$,
198.7, 130.9, 92.5, 69.2, 33.3, 31.8, 31.2, 24.4 ppm; HRMS-ESI $(m / z):[\mathrm{M}+\mathrm{Na}]^{+}$calcd for $\mathrm{C}_{9} \mathrm{H}_{12} \mathrm{~N}_{2} \mathrm{O}_{3}, 219.0746$; found, 219.0746 .

B. Sensitized photoexcitation of 2-diazo-3a,4,7,7a-tetrahydro- $1 H-4,7-m e t h a n o i n d e n e-1,3(2 H)$-dione (1b). The reaction was performed according to the general procedure with $380 \mathrm{mg}$ ( $2 \mathrm{mmol}, 1$ equiv) of diazodiketone $\mathbf{1 b}$ and $3.64 \mathrm{~g}$ (20 mmol, 10 equiv) of benzophenone in $20 \mathrm{ml}$ of THF with an irradiation time of $90 \mathrm{~min}$. After the standard workup procedure hydrazone $\mathbf{2 b}$ was isolated.

2-(2-(Tetrahydrofuran-2-yl)hydrazono)-3a,4,7,7a-tetrahydro-1H-4,7-methanoindene-1,3(2H)-dione (2b). Yield $374 \mathrm{mg}$ (71\%); bright-yellow solid; mp $127-129{ }^{\circ} \mathrm{C}$; ${ }^{1} \mathrm{H}$ NMR (400 MHz, $\left.\mathrm{CDCl}_{3}, \delta\right) 12.78(\mathrm{~s}, 1 \mathrm{H}), 6.11-5.98(\mathrm{~m}, 1 \mathrm{H})$, 6.00-5.87 (m, 1H), 5.54-5.41 (m, 1H), 4.05-3.94 (m, 1H), 3.92-3.82 (m, 1H), $3.38(\mathrm{~d}, J=20.3 \mathrm{~Hz}, 2 \mathrm{H}), 3.20-3.07(\mathrm{~m}$, $2 \mathrm{H}), 2.32-2.10(\mathrm{~m}, 2 \mathrm{H}), 2.03-1.92(\mathrm{~m}, 2 \mathrm{H}), 1.63(\mathrm{dt}, J=8.6$, $1.5 \mathrm{~Hz}, 1 \mathrm{H}), 1.48(\mathrm{~d}, J=8.6 \mathrm{~Hz}, 1 \mathrm{H}) \mathrm{ppm} ;{ }^{13} \mathrm{C} \mathrm{NMR}$ $\left(101 \mathrm{MHz}, \mathrm{CDCl}_{3}, \delta\right) 201.3,199.51,199.49,134.9,134.8$, $133.7,133.63,133.55,133.53,92.44,92.39,69.0,68.9,52.39$, 52.37, 49.8, 48.2, 48.14, 46.14, 46.11, 46.04, 46.00, 31.2, 31.1, 24.4, $24.3 \mathrm{ppm} ;{ }^{1} \mathrm{H}$ NMR (400 MHz, acetone- $\left.d_{6}, \delta\right) 6.36-5.71$ (m, 2H), $5.48(\mathrm{dd}, J=6.6,3.6 \mathrm{~Hz}, 1 \mathrm{H}), 4.14-3.75(\mathrm{~m}, 2 \mathrm{H})$, $3.46-3.01(\mathrm{~m}, 5 \mathrm{H}), 2.46-2.12(\mathrm{~m}, 2 \mathrm{H}), 2.10-1.73(\mathrm{~m}, 2 \mathrm{H})$, $1.62-1.52(\mathrm{~m}, 2 \mathrm{H}) \mathrm{ppm} ;{ }^{13} \mathrm{C}$ NMR $\left(101 \mathrm{MHz}\right.$, acetone- $\left.d_{6}, \delta\right)$ 199.8, 134.1, 133.7, 92.1, 68.5, 52.0, 48.8, 45.9, 30.3, 24.4 ppm; HRMS-ESI $(m / z)$ : $[\mathrm{M}+\mathrm{Na}]^{+}$calcd for $\mathrm{C}_{14} \mathrm{H}_{16} \mathrm{~N}_{2} \mathrm{O}_{3}$, 283.1059; found, 283.1065 .

C. Sensitized photoexcitation of 2-diazohexahydro-1 H-4,7methanoindene-1,3(2H)-dione (1c). The reaction was performed according to the general procedure with $376 \mathrm{mg}$ ( $2 \mathrm{mmol}, 1$ equiv) of diazodiketone $1 \mathrm{c}$ and $3.64 \mathrm{~g}(20 \mathrm{mmol}$, 10 equiv) of benzophenone in $20 \mathrm{ml}$ of THF with an irradiation time of $1 \mathrm{~h}$. After the standard workup procedure hydrazone $\mathbf{2 c}$ was isolated.

2-(2-(Tetrahydrofuran-2-yl)hydrazono)hexahydro-1 $\boldsymbol{H}-4,7-$ methanoindene-1,3(2H)-dione (2c). Yield $328 \mathrm{mg}$ (63\%); bright-yellow oil; ${ }^{1} \mathrm{H}$ NMR (400 MHz, $\left.\mathrm{CDCl}_{3}, \delta\right) 13.10$ (broad, $1 \mathrm{H}, \mathrm{NH}), 5.66-5.51(\mathrm{~m}, 1 \mathrm{H}), 4.11-4.01(\mathrm{~m}, 1 \mathrm{H}), 3.98-3.89(\mathrm{~m}$, $1 \mathrm{H}), 3.02-2.90(\mathrm{~m}, 2 \mathrm{H}), 2.75-2.86(\mathrm{~m}, 2 \mathrm{H}), 2.37-2.19(\mathrm{~m}, 2 \mathrm{H})$, 2.11-1.99 (m, 2H), 1.65-1.54 (m, 2H), 1.53-1.44 (m, 2H), $1.39-1.31(\mathrm{~m}, 1 \mathrm{H}), 1.27-1.15(\mathrm{~m}, 1 \mathrm{H}) \mathrm{ppm} ;{ }^{13} \mathrm{C} \mathrm{NMR}$

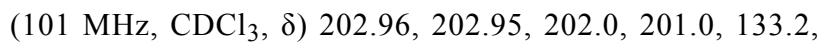
133.0, 92.7, 92.6, 69.2, 69.1, 52.68, 52.65, 50.99, 50.98, 42.49, $42.47,40.62,40.59,40.55,40.52,31.34,31.26,24.7,24.59$, 24.56, 24.5, 24.4 ppm; HRMS-ESI $(\mathrm{m} / \mathrm{z}):[\mathrm{M}+\mathrm{Na}]^{+}$calcd for $\mathrm{C}_{14} \mathrm{H}_{18} \mathrm{~N}_{2} \mathrm{O}_{3}, 285.1215$; found, 285.1210 . 
D. Sensitized photoexcitation of 2-diazo-3a,4,7,7a-tetrahydro-1H-4,7-epoxyindene-1,3(2H)-dione (1d). The reaction was performed according to the general procedure with $380 \mathrm{mg}$ ( 2 mmol, 1 equiv) of diazodiketone $1 \mathbf{d}$ and $1.46 \mathrm{~g}$ ( $8 \mathrm{mmol}$, 4 equiv) of benzophenone in $20 \mathrm{ml}$ of THF with an irradiation time of $0.5 \mathrm{~h}$. After the standard workup procedure hydrazones 2d, $\mathbf{3}$ and unreacted diazoketone 1d were isolated.

2-(2-(Tetrahydrofuran-2-yl)hydrazono)-3a,4,7,7a-tetrahydro-1H-4,7-epoxyindene-1,3(2H)-dione (2d). Yield $134 \mathrm{mg}$ (35\% based on reacted diazodiketone 1d); yellow oil; ${ }^{1} \mathrm{H}$ NMR (400 MHz, $\left.\mathrm{CDCl}_{3}, \delta\right) 12.83$ (broad, 1H), 6.67-6.31 (m, 2H), $5.60-5.49(\mathrm{~m}, 1 \mathrm{H}), 5.29(\mathrm{~s}, 1 \mathrm{H}), 5.23(\mathrm{~s}, 1 \mathrm{H}), 4.10-3.95(\mathrm{~m}$, $1 \mathrm{H}), 3.98-3.85(\mathrm{~m}, 1 \mathrm{H}), 2.76-2.60(\mathrm{~m}, 2 \mathrm{H}), 2.34-2.20(\mathrm{~m}, 2 \mathrm{H})$, 2.11-1.89 (m, 2H) ppm; ${ }^{13} \mathrm{C}$ NMR (101 MHz, $\left.\mathrm{CDCl}_{3}, \delta\right)$ 198.73, 198.70, 197.37, 197.36, 137.4, 136.8 133.50, 133.46, 92.7, 92.4, 82.5, 81.8, 69.25, 69.22, 51.01, 50.99, 49.51, 49.48, 31.3, 31.2, 24.3 ppm; HRMS-ESI $(\mathrm{m} / \mathrm{z}):[\mathrm{M}+\mathrm{H}]^{+}$calcd for $\mathrm{C}_{13} \mathrm{H}_{14} \mathrm{~N}_{2} \mathrm{O}_{4}, 263.1032$; found, 263.1029.

2-(2-(Tetrahydrofuran-2-yl)hydrazono)cyclopent-4-ene-1,3dione (3). Yield $135 \mathrm{mg}$ (47\%, on the reacted diazodiketone 1d); yellow oil; ${ }^{1} \mathrm{H} \mathrm{NMR}\left(400 \mathrm{MHz}, \mathrm{CDCl}_{3}, \delta\right) 11.07(\mathrm{~s}, 1 \mathrm{H})$, 7.09 (d, $J=6.7 \mathrm{~Hz}, 1 \mathrm{H}), 7.05(\mathrm{~d}, J=6.7 \mathrm{~Hz}, 1 \mathrm{H}), 5.62-5.45(\mathrm{~m}$, 1H), 4.13-3.79 (m, 1H), 2.40-1.75 (m, 1H) ppm; ${ }^{13} \mathrm{C}$ NMR (101 $\left.\mathrm{MHz}, \mathrm{CDCl}_{3}, \delta\right)$ 191.9, 189.9, 145.8, 143.5, 137.0, 91.5, 68.5, 30.7, 24.7 ppm; HRMS-ESI $(\mathrm{m} / \mathrm{z}):[\mathrm{M}+\mathrm{H}]^{+}$calcd for $\mathrm{C}_{9} \mathrm{H}_{10} \mathrm{~N}_{2} \mathrm{O}_{3}, 195.0770$; found, 195.0774.

E. Sensitized photoexcitation of 2-diazo-4-methyl-3a,4,7,7atetrahydro-1H-4,7-epoxyindene-1,3(2H)-dione (2e). The reaction was performed according to the general procedure with $204 \mathrm{mg}$ ( $2 \mathrm{mmol}, 1$ equiv) of diazoketone $1 \mathrm{e}$ and $728 \mathrm{mg}$ ( $8 \mathrm{mmol}, 4$ equiv) of benzophenone in $10 \mathrm{ml}$ of THF with an irradiation time of $1 \mathrm{~h}$. After the workup procedure hydrazone 3 [66 mg (34\%)] was isolated exclusively.

\section{F. Sensitized photoexcitation of 2-diazo- $1 H$-indene-1,3(2H)-} dione (2f). The reaction was performed according to the general procedure with $344 \mathrm{mg}$ ( $2 \mathrm{mmol}, 1$ equiv) of diazodiketone $\mathbf{1 f}$ and $1.46 \mathrm{~g} \mathrm{(} 8 \mathrm{mmol}, 4$ equiv) of benzophenone in $20 \mathrm{ml}$ of THF with and irradiation time of $0.8 \mathrm{~h}$. After standard workup procedure hydrazone $\mathbf{2 f}$ and unreacted diazodiketone $\mathbf{1 f}$ were isolated.

2-(2-(Tetrahydrofuran-2-yl)hydrazono)-1 $H$-indene-1,3(2H)dione (2f). Yield $70 \mathrm{mg}(52 \%$, calculated on the reacted diazodiketone 1f); yellow oil; ${ }^{1} \mathrm{H} \mathrm{NMR}\left(400 \mathrm{MHz}, \mathrm{CDCl}_{3}, \delta\right)$ 11.79 (broad, 1H), 7.96-7.85 (m, 1H), 7.84-7.77 (m, 1H), 7.77-7.65 (m, 2H), 5.71-5.45 (m, 1H), 4.14-3.95 (m, 1H), 3.96-3.67 (m, 1H), 2.44-2.12 (m, 2H), 2.15-1.70 (m, 2H) ppm;
${ }^{13} \mathrm{C}$ NMR $\left(101 \mathrm{MHz}, \mathrm{CDCl}_{3}, \delta\right) 188.3,186.4,140.2,138.6$, 135.1, 134.8, 130.1, 123.1, 122.7, 91.9, 68.6, 31.0, 24.7 ppm; HRMS-ESI $(\mathrm{m} / \mathrm{z}):[\mathrm{M}+\mathrm{H}]^{+}$calcd for $\mathrm{C}_{13} \mathrm{H}_{12} \mathrm{~N}_{2} \mathrm{O}_{3}, 245.0926$; found, 245.0926 .

\section{Direct photolysis of diazodiketones 1a-c}

Photolysis of diazodiketone 1a (with $\mathrm{H}_{2} \mathrm{O}$ ). A solution of sublimated diazodiketone $1 \mathrm{a}(1.24 \mathrm{~g}, 0.01 \mathrm{~mol})$ in $90 \mathrm{ml}$ of pure anhydrous THF and distilled $\mathrm{H}_{2} \mathrm{O}(1.8 \mathrm{ml}, 0.1 \mathrm{~mol})$ was irradiated in a quartz reactor $(\lambda>210 \mathrm{~nm})$ for 50 min until complete disappearance of diazodiketone 1a (control by TLC). Then the reaction mixture was dried with magnesium sulfate and the solvent distilled off in vacuum. The obtained residue was dissolved in $25 \mathrm{ml}$ of anhydrous $\mathrm{Et}_{2} \mathrm{O}$, cooled to -75 to $-78{ }^{\circ} \mathrm{C}$. The precipitated resinous matter was separated by decantation and the solvent was completely removed in vacuum. The resulting oily residue was taken up in 2-3 $\mathrm{ml}$ of anhydrous $\mathrm{Et}_{2} \mathrm{O}$ and separated by column chromatography $(5 \mathrm{~g}$ of anhydrous neutral $\mathrm{SiO}_{2}$; eluent: anhydrous diethyl ether) to give acid $\mathbf{4 a}$ as a crystalline solid after usual workup and careful removal of solvent in vacuum from the proper fractions $(0.5-0.1 \mathrm{~mm} \mathrm{Hg})$.

Cyclobutane-2-one carboxylic acid (4a) [46,47]. Yield $1.03 \mathrm{~g}(90 \%) ; \mathrm{mp} 43-44.5{ }^{\circ} \mathrm{C}$ (distilled); bp 93.5-94 ${ }^{\circ} \mathrm{C}$ $(0.2-0.1 \mathrm{~mm} \mathrm{Hg})$. It is noteworthy that acid $\mathbf{4 a}$ is a very hygroscopic compound which is easily hydrolyzed to produce glutaric acid.

Photolysis of diazodiketone 1a (with MeOH). A solution of sublimated diazodiketone 1a $(2.48 \mathrm{~g}, 0.02 \mathrm{~mol})$ in $80 \mathrm{ml}$ of anhydrous THF and pure $\mathrm{CH}_{3} \mathrm{OH}(4 \mathrm{ml}, 0.10 \mathrm{~mol})$ was irradiated in a quartz reactor $(\lambda>210 \mathrm{~nm})$ for $55 \mathrm{~min}$ and worked up similarly as described in the previous experiment. The resulting reaction mixture after removal of THF and methanol in vacuum was distilled to give methyl ester $\mathbf{5 a}$.

Methyl cyclobutane-2-one carboxylate (5a) [48]. Yield $2.20 \mathrm{~g}$ (86\%); bp $43.5-45{ }^{\circ} \mathrm{C}(1 \mathrm{~mm} \mathrm{Hg}) ; n_{\mathrm{D}}{ }^{20}$ 1.5111. During column chromatography with $\mathrm{SiO}_{2}$ of I or II activity, methyl ester 5a considerably hydrolyzes to give Me ester of glutaric acid.

Photolysis of diazodiketone $1 \mathrm{~b}$ (with $\mathrm{MeOH})$. A solution of diazodiketone $\mathbf{1 b}(141 \mathrm{mg}, 0.75 \mathrm{mmol})$ in $10 \mathrm{ml}$ of THF/ $\mathrm{CH}_{3} \mathrm{OH}$ 200:1 was irradiated for $55 \mathrm{~min}$ in a quartz reactor $(\lambda>210 \mathrm{~nm})$. Then the reaction mixture was dried with magnesium sulfate and the solvent and excess of $\mathrm{CH}_{3} \mathrm{OH}$ were completely removed in vacuum. The residue containing ester $\mathbf{5 b}$ (140 mg; 97\% by ${ }^{1} \mathrm{H}$ NMR) was separated by preparative TLC to furnish Me ester $\mathbf{5 b}$. 
Methyl 4-oxotricyclo[4.2.1.02,5]non-7-ene-3-carboxylate (5b). Yield $114 \mathrm{mg}$ (79\%; 97\% by ${ }^{1} \mathrm{H}$ NMR); colorless oil; ${ }^{1} \mathrm{H}$ NMR (400 MHz, $\left.\mathrm{CDCl}_{3}, \delta\right)$ 6.23-6.19 (m, 2H), 4.02-3.80 (m, $1 \mathrm{H}), 3.71(\mathrm{~s}, 3 \mathrm{H}), 3.32-2.99(\mathrm{~m}, 4 \mathrm{H}), 1.82-1.75(\mathrm{~m}, 1 \mathrm{H})$, $1.53-1.47$ (m, 1H) ppm; ${ }^{13} \mathrm{C}$ NMR $\left(101 \mathrm{MHz}, \mathrm{CDCl}_{3}, \delta\right)$ 201.4, $167.8,136.2,133.4,67.1,63.9,54.3,52.4,46.6,43.9,30.8$ ppm; HRMS-ESI $(\mathrm{m} / \mathrm{z}):[\mathrm{M}+\mathrm{Na}]^{+}$calcd for $\mathrm{C}_{11} \mathrm{H}_{12} \mathrm{O}_{3}$, 215.0684; found, 215.0681 .

Photolysis of diazodiketone 1c (with $\mathrm{MeOH}$ ). A solution of diazodiketone 1c (190 mg, $1 \mathrm{mmol})$ in $10 \mathrm{ml}$ of THF/MeOH $50: 1$ was irradiated in a quartz reactor $(\lambda>210 \mathrm{~nm})$ for $45 \mathrm{~min}$. Then the reaction mixture was dried with magnesium sulfate and the solvent and excess of $\mathrm{CH}_{3} \mathrm{OH}$ were completely distilled off in vacuum. The residue, containing ester 5c (189 mg; $98 \%$ by ${ }^{1} \mathrm{H}$ NMR) was separated by preparative TLC to give pure methyl ester $\mathbf{5 c}$.

Methyl 4-oxotricyclo[4.2.1.0 $\left.{ }^{2,5}\right]$ nonane-3-carboxylate (5c). Yield $158 \mathrm{mg}$ (82\%); colorless oil; ${ }^{1} \mathrm{H}$ NMR (400 MHz, $\mathrm{CDCl}_{3}$, б) $3.92-3.87(\mathrm{~m}, 1 \mathrm{H}), 3.75-3.66(\mathrm{~m}, 4 \mathrm{H}), 3.06-2.99(\mathrm{~m}, 1 \mathrm{H})$, 2.63-2.57 (m, 1H), 2.59-2.50 (m, 1H), 1.65-1.53 (m, 5H), 1.41-1.33 (m, 1H) ppm; ${ }^{13} \mathrm{C}$ NMR (101 MHz, $\left.\mathrm{CDCl}_{3}, \delta\right) 203.7$, 168.2, 69.6, 61.6, 52.5, 43.7, 40.8, 38.9, 34.9, 25.7, 24.6 ppm; HRMS-ESI $(\mathrm{m} / \mathrm{z})$ : $[\mathrm{M}+\mathrm{Na}]^{+}$calcd for $\mathrm{C}_{11} \mathrm{H}_{14} \mathrm{O}_{3}, 217.0841$; found, 217.0835 .

\section{Supporting Information}

\section{Supporting Information File 1}

NMR spectra of all new compounds and data of X-ray analysis for compounds 1c (CCDC 1584937) and 2b (CCDC 1584938).

[https://www.beilstein-journals.org/bjoc/content/ supplementary/1860-5397-14-200-S1.pdf]

\section{Acknowledgements}

The authors express their gratitude to the SPbSU resource centers: "Center for Magnetic Resonance", "Chemical Analysis and Materials Research Centre" and "Resource Education Center" and "Research Centre for X-Ray Diffraction Methods of Investigation". J.J.M. gratefully acknowledges generous financial support from "Russian Foundation for Basic Research" (RFBR, \# 16-33-00059 mol_a).

\section{ORCID ${ }^{\circledR}$ iDs}

Liudmila L. Rodina - https://orcid.org/0000-0002-6549-7033 Xenia V. Azarova - https://orcid.org/0000-0002-9960-8408 Jury J. Medvedev - https://orcid.org/0000-0002-4156-7455 Valerij A. Nikolaev - https://orcid.org/0000-0001-5517-484X

\section{References}

1. Ford, A.; Miel, H.; Ring, A.; Slattery, C. N.; Maguire, A. R.; McKervey, M. A. Chem. Rev. 2015, 115, 9981-10080. doi:10.1021/acs.chemrev.5b00121

2. Galkina, O. S.; Rodina, L. L. Russ. Chem. Rev. 2016, 85, 537-555. doi:10.1070/RCR4519

3. Candeias, N. R.; Afonso, C. A. M. Curr. Org. Chem. 2009, 13, 763-787. doi:10.2174/138527209788167231

4. Zhang, Z.; Wang, J. Tetrahedron 2008, 64, 6577-6605. doi:10.1016/j.tet.2008.04.074

5. Kirmse, W. Eur. J. Org. Chem. 2002, 2193-2256. doi:10.1002/1099-0690(200207)2002:14<2193::aid-ejoc2193>3.0.co;2d

6. Bertrand, G., Ed. Carbene Chemistry; Marcel Dekker: New York, NY, U.S.A., 2002; p 320. doi:10.1201/9780203910924

7. Platz, M. S., Ed. Kinetics and Spectroscopy of Carbenes and Biradicals; Plenum Press: New York, NY, U.S.A., 1990; p 372. doi:10.1007/978-1-4899-3707-0

8. Ross, M. J.; Moss, R. A. Carbene Chemistry; John Wiley \& Sons Inc.: New York, NY, U.S.A., 1975.

9. Moss, R. A.; Jones, M., Jr. Carbenes; John Wiley \& Sons: New York, NY, U.S.A., 1973.

10. Kirmse, W. Carbenes, 2nd ed.; Academic Press: New York, NY, U.S.A., 1971.

11. Tidwell, T. T. Angew. Chem., Int. Ed. 2005, 44, 5778-5785. doi:10.1002/anie.200500098

12. Garbarino, S.; Banfi, L.; Riva, R.; Basso, A. J. Org. Chem. 2014, 79, 3615-3622. doi:10.1021/jo500535f

13. Burdzinski, G.; Kubicki, J.; Sliwa, M.; Réhault, J.; Zhang, Y.; Vyas, S.; Luk, H. L.; Hadad, C. M.; Platz, M. S. J. Org. Chem. 2013, 78, 2026-2032. doi:10.1021/jo302023a

14. Willumstad, T. P.; Haze, O.; Mak, X. Y.; Lam, T. Y.; Wang, Y.-P.; Danheiser, R. L. J. Org. Chem. 2013, 78, 11450-11469. doi:10.1021/jo402010b

15. Burdzinski, G.; Zhang, Y.; Wang, J.; Platz, M. S. J. Phys. Chem. A 2010, 114, 13065-13068. doi:10.1021/jp108690n

16. Wolpert, D.; Schade, M.; Brixner, T. J. Chem. Phys. 2008, 129, 094504. doi:10.1063/1.2971037

17. Nikolaev, V. A.; Shevchenko, V. V.; Platz, M. S.; Khimich, N. N. Russ. J. Org. Chem. 2006, 42, 815-827. doi:10.1134/S1070428006060029

18. Popik, V. V. Can. J. Chem. 2005, 83, 1382-1390. doi:10.1139/v05-152 19. Korneev, S. M. Eur. J. Org. Chem. 2011, 6153-6175. doi:10.1002/ejoc.201100224

20. Shevchenko, V. V.; Khimich, N. N.; Platz, M. S.; Nikolaev, V. A. Tetrahedron Lett. 2005, 46, 435-438. doi:10.1016/j.tetlet.2004.11.102

21. Bogdanova, A.; Popik, V. V. J. Am. Chem. Soc. 2004, 126, 11293-11302. doi:10.1021/ja047824r

22. Meier, H. Diazirine-Diazoalkane Interconversions. In Chemistry of diazirines; Liu, M. T. H., Ed.; CRC Press: Boca Raton, FL, U.S.A., 1987; pp 1-19.

23. Nikolaev, V. A.; Khimich, N. N.; Korobitsyna, I. K. Chem. Heterocycl. Compd. 1985, 21, 264-268. doi:10.1007/bf00506661 Khim. Geterotsikl. Soedin. 1985, 321-325.

24. Livinghouse, T.; Stevens, R. V. J. Am. Chem. Soc. 1978, 100, 6479-6482. doi:10.1021/ja00488a036

25. Voigt, E.; Meier, H. Chem. Ber. 1975, 108, 3326-3335. doi:10.1002/cber.19751081025 
26. Lowe, G.; Parker, J. J. Chem. Soc. D 1971, 577-578. doi:10.1039/c29710000577

27. Rodina, L. L.; Baranovskii, V. I.; Galkina, O. S.; Nikolaev, V. A.; Tonogina, N. L.; Povolotskiy, A. V. J. Org. Chem. 2017, 82, 11399-11405. doi:10.1021/acs.joc.7b01848

28. Rodina, L. L.; Galkina, O. S.; Maas, G.; Platz, M. S.; Nikolaev, V. A. Asian J. Org. Chem. 2016, 5, 691-698. doi:10.1002/ajoc.201600050

29. Nikolaev, V. A.; Galkina, O. S.; Sieler, J.; Rodina, L. L. Tetrahedron Lett. 2010, 51, 2713-2716. doi:10.1016/j.tetlet.2010.03.050

30. Galkina, O. S. Ph.D. Thesis, Saint-Petersburg State University, 2015

31. Presset, M.; Mailhol, D.; Coquerel, Y.; Rodriguez, J. Synthesis 2011, 2549-2552. doi:10.1055/s-0030-1260107

32. Wu, C.; Mooring, A. M.; Yardley, J. T. UV photoresist containing polycyclic cyclopentanediazodione derivative. Eur. Pat. Appl. EP405957A1, Jan 2, 1991.

33. Korobitsyna, I. K.; Rodina, L. L.; Nikolaev, V. A. The method of producing bicyclic diazocyclopentanediones. Patent of the USSR 1004359, March 15, 1983.

34. Regitz, M.; Maas, G. Diazo Compounds. Properties and Synthesis; Academic Press: New York, NY, U.S.A., 1986. doi:10.1016/b978-0-12-585840-3.x5001-6

35. Doyle, M. P.; McKervey, M. A.; Ye, T. Modern Catalytic Methods for Organic Synthesis with Diazo Compounds; John Wiley \& Sons Inc.: New York, NY, U.S.A., 1998.

36. Baum, J. S.; Shook, D. A.; Davies, H. M. L.; Smith, H. D. Synth. Commun. 1987, 17, 1709-1716. doi:10.1080/00397918708063988

37. Popic, V. V.; Korneev, S. M.; Nikolaev, V. A.; Korobitsyna, I. K. Synthesis 1991, 195-198. doi:10.1055/s-1991-26416

38. Nikolaev, V. A.; Korobitsyna, I. K. Procedure for preparation of 2-diazo-1,3-dioxoceclopentene. Patent of the USSR 1172224, May 13, 1985.

39. Oda, M.; Kasai, M.; Kitahara, Y. Chem. Lett. 1977, 6, 307-310. doi:10.1246/cl.1977.307

40. Csizmadia, I. G.; Houlden, S. A.; Meresz, O.; Yates, P. Tetrahedron 1969, 25, 2121-2138. doi:10.1016/s0040-4020(01)82763-0

41. Turro, N. J.; Ramamurthy, V.; Scaiano, J. C. Principles of molecular photochemistry: an introduction; University Science Books: Sausalito, CA, U.S.A., 2009.

42. Candeias, N. R.; Gois, P. M. P.; Veiros, L. F.; Afonso, C. A. M. J. Org. Chem. 2008, 73, 5926-5932. doi:10.1021/jo800980c

43. Buchner, M. R.; Wahl, B.; Ruhland, K. J. Photochem. Photobiol., A 2013, 252, 183-193. doi:10.1016/j.jphotochem.2012.12.005

44. Rau, H.; Bokel, M. J. Photochem. Photobiol., A 1990, 53, 311-322. doi:10.1016/1010-6030(90)87135-x

45. Corey, E. J.; Felix, A. M. J. Am. Chem. Soc. 1965, 87, 2518-2519. doi:10.1021/ja01089a055

46. Chang, J. A.; Chiang, Y.; Keeffe, J. R.; Kresge, A. J.; Nikolaev, V. A.; Popik, V. V. J. Org. Chem. 2006, 71, 4460-4467. doi:10.1021/jo060253w

47. Amice, P.; Conia, J. M. Tetrahedron Lett. 1974, 15, 479-482. doi:10.1016/s0040-4039(01)82249-8

48. Kniep, C. S.; Padias, A. B.; Hall, H. K., Jr. Tetrahedron 2000, 56, 4279-4288. doi:10.1016/s0040-4020(00)00354-9

49. Bogdanova, A.; Popik, V. V. J. Am. Chem. Soc. 2003, 125, 1456-1457. doi:10.1021/ja029528p

50. Bogdanova, A.; Popik, V. V. J. Am. Chem. Soc. 2003, 125, 14153-14162. doi:10.1021/ja037637d
51. Nikolaev, V. A.; Frenkh, Y.; Korobitsyna, I. K. J. Org. Chem. USSR 1978, 14, 1338-1346.

52. Klan, P.; Wirz, J. Photochemistry of organic compounds: from concepts to practice; Wiley: West Sussex, United Kingdom, 2009. doi:10.1002/9781444300017

53. Maas, G.; Krebs, F.; Werle, T.; Gettwert, V.; Striegler, R. Eur. J. Org. Chem. 1999, 1939-1946. doi:10.1002/(sici)1099-0690(199908)1999:8<1939::aid-ejoc1939>3.0.c o;2-a

54. Hudlicky, T.; Ranu, B. C.; Naqvi, S. M.; Srnak, A. J. Org. Chem. 1985, 50, 123-127. doi:10.1021/jo00201a026

55. Hudlicky, T.; Sheth, J. P.; Gee, V.; Barnvos, D. Tetrahedron Lett. 1979, 20, 4889-4892. doi:10.1016/s0040-4039(01)86741-1

56. Palatinus, L.; Chapuis, G. J. Appl. Crystallogr. 2007, 40, 786-790. doi:10.1107/S0021889807029238

57. Palatinus, L.; van der Lee, A. J. Appl. Crystallogr. 2008, 41, 975-984. doi:10.1107/s0021889808028185

58. Palatinus, L.; Prathapa, S. J.; van Smaalen, S. J. Appl. Crystallogr. 2012, 45, 575-580. doi:10.1107/S0021889812016068

59. Sheldrick, G. M. Acta Crystallogr., Sect. A: Found. Crystallogr. 2008, 64, 112-122. doi:10.1107/s0108767307043930

60. Sheldrick, G. M. Acta Crystallogr., Sect. A: Found. Adv. 2015, 71, 3-8. doi:10.1107/s2053273314026370

61. Dolomanov, O. V.; Bourhis, L. J.; Gildea, R. J.; Howard, J. A. K.; Puschmann, H. J. Appl. Crystallogr. 2009, 42, 339-341. doi:10.1107/S0021889808042726

\section{License and Terms}

This is an Open Access article under the terms of the Creative Commons Attribution License (http://creativecommons.org/licenses/by/4.0). Please note that the reuse, redistribution and reproduction in particular requires that the authors and source are credited.

The license is subject to the Beilstein Journal of Organic Chemistry terms and conditions:

(https://www.beilstein-journals.org/bjoc)

The definitive version of this article is the electronic one which can be found at: doi:10.3762/bjoc. 14.200 